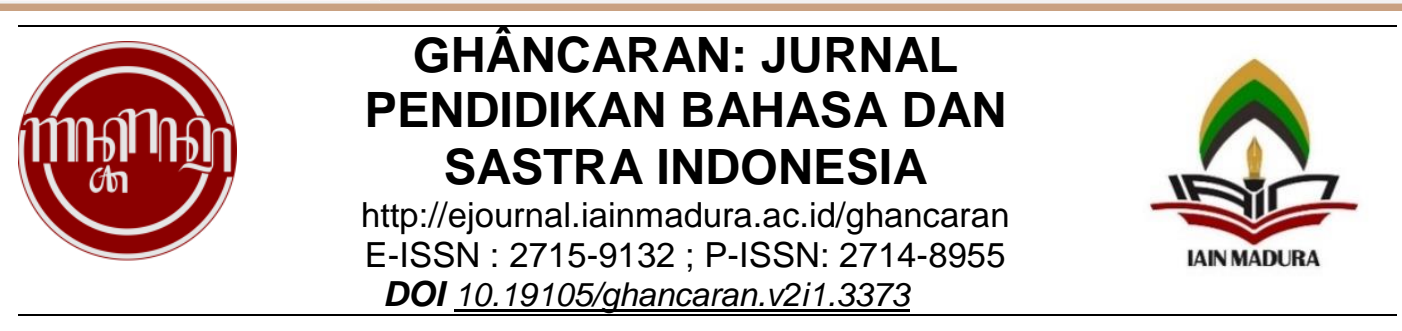

\title{
AKTUALISASI BAHASA JAWA YOUTUBER UPAYA PEMERTAHANAN BAHASA JAWA PADA MASA PANDEMI COVID-19
}

\author{
Moh. Arif Susanto*, Elita Arcelina Sandi** \\ * Pendidikan Bahasa dan Sastra Indonesia, Universitas PGRI Wiranegara Pasuruan \\ ${ }^{*}$ S2 Pendidikan Bahasa dan Sastra, Universitas Negeri Surabaya \\ Alamat surel: bhsindo1@gmail.com
}

\begin{tabular}{ll}
\hline \hline & Abstract \\
\hline Keywords: & This study describes the strategy of retaining Javanese during the \\
Javanese & Covid-19 pandemic, using a descriptive qualitative explanative \\
language & approach. The results show that Javanese language retention \\
preservation; & efforts through mass media are less effective, conventionally \\
Covidemic; & through classroom learning and activities that invite the masses \\
Youtuber. & need to be evaluated because of the pandemic. Youtuber through \\
& Javanese content, currently gaining popularity, has followers not \\
& only Javanese speakers. Youtube content can be used as an \\
& alternative effort in maintaining Javanese, through Javanese \\
& language content contests. Javanese language content competition \\
& is low cost, wide-reaching and does not violate health protocol rules \\
& during the Covid-19 pandemic.
\end{tabular}

\begin{tabular}{ll}
\hline \hline & Abstrak: \\
\hline Kata Kunci: & Kajian ini mendeskripsikan strategi pemertahanan bahasa Jawa \\
Pemertahanan & pada masa pandemi Covid-19. Menggunakan pendekatan kualitatif \\
Bahasa Jawa; & deskriptif eksplanatif. Hasil menunjukkan upaya pemertahanan \\
Youtuber. & bahasa Jawa melalui media massa kurang efektif, secara \\
& konvensional melalui pembelajaran di kelas dan kegiatan yang \\
& mengundang massa perlu dievaluasi karena pandemi. Youtuber \\
& melalui konten berbahasa Jawa, saat ini meraih popularitas, \\
& memiliki pengikut tidak hanya penutur bahasa Jawa. Konten \\
& youtube dapat dijadikan upaya alternatif dalam pemertahanan \\
& bahasa Jawa, melalui lomba konten berbahasa Jawa. Lomba \\
& konten berbahasa Jawa berbiaya murah, jangkauan luas dan tidak \\
& menyalahi aturan protokol kesehatan pada masa pandemi Covid- \\
& 19. \\
\hline \hline Terkirim : 19 Mei 2020; Revisi: 17 Juli 2020; & Diterima: 22 Juli 2020 \\
\hline \hline OGhâncaran: Jurnal Pendidikan Bahasa dan Sastra Indonesia \\
Institut Agama Islam Negeri Madura, Indonesia
\end{tabular}

\section{PENDAHULUAN}

Bahasa Jawa adalah bahasa daerah yang paling banyak penuturnya, dibandingkan dengan bahasa derah lain di Indonesia. Crystal (dalam Lauder, 2004) menyatakan bahasa Jawa merupakan satu di anatara tiga belas bahasa terbesar di Indonesia dengan jumlah penutur 75,2 Juta. Walaupun bahasa Jawa termasuk dalam bahasa daerah yang banyak penuturnya, keberadaannya bukanlah tanpa ancaman kepunahan. Ancaman tersebut senantiasa mengintai, faktor penyebab salah satunya, penutur bahasa Jawa saat ini cenderung multilingual tidak menggunaan bahasa tersebut secara monolingual dalam berkomunikasi. Salah satu sebab penggunaan 
bahasa multilingual adalah pada era global saat ini tidak memungkinkan memakai bahasa secara monolingual, pemakaian bahasa cenderung multilingual (Gumperz 1971). Dalam satu wilayah dimungkinkan hidup beberapa varietas bahasa secara berdampingan sehingga dimungkinkan bentuk interaksi menggunakan campur kode dan alih kode (Fasold 1984). Interaksi multilingual tersebut lambat laun akan mengancam keberadaan bahasa Jawa.

Penelitian tentang ancaman kepunahan bahasa Jawa pernah dilakukan Oleh Revindranath (2014) dengan berjudul penelitian "Local Languages In Indonesia: Language Maintenance Or Language Shift?" hasil penelitian menunjukkan ancaman kepunahan bahasa Jawa disebabkan oleh. Pertama, besarnya peran bahasa Indonesia dalam kehidupan sehari-hari, bahasa Indonesia dipakai dalam ranah keluarga, pendidikan, ekonami dan budaya. Kedua, kurangnya minat generasi muda untuk menggunakan bahasa Jawa.

Hanna (2012) dalam makalah yang berjudul "Bahasa Daerah Pada Era Globalisasi Peluang dan Tantangannya" menyampaikan bahwa bahasa daerah hidup dalam masa yang memprihatinkan. Generasi muda saa ini dalam berkomunikasi baik dalam kehidupan sehari-hari maupun dalam berkomunikasi di rumah tangga enggan menggunakan bahasa daerah. la menyebutkan keprihatinan tersebut semakin parah karena masyarakat memiliki persepsi negatif terhadap bahasa daerah, dan cenderung meninggalkan ketika mereka hidup dalam era yang semakin modern. Dengan kata lain ancaman tersebut juga mengarah pada bahasa Jawa. Bahasa Jawa adalah bahasa daerah yang memiliki posisi sama seperti bahasa daerah lainnya, penutur cenderung malu menggunakan bahasa daerah karena gengsi.

Berdasarkan uraian di atas ancaman kepunahan bahasa Jawa bukanlah isapan jempol, masalah tersebut menjadi ancaman nyata. UNESCO memprediksi dalam jangka waktu satu abad lagi, 50\% dari sekitar 6.700 bahasa di dunia akan mengalami kepunahan. Prediksi tersebut tentu berlaku bagi sejumlah bahasa daerah di Indonesia (Mbete 2010). Bahasa Jawa tidak terlepas dari ancaman tersebut. Maka upaya pemertahanan bahasa perlu digalakkan.

Upaya pemertahanan bahasa Jawa sebenarnya telah diusahakan. Beberapa usaha diantaranya: Pertama, Penggunaan bahasa Jawa pada media massa pemerintah maupun swasta, melalui pemberitaan dan hiburan. TVRI Jawa Timur, TVRI Jawa Tengah, TVRI Yogyakarta, Arek TV, JTV, Jogja TV terdapat acara yang khusus menggunakan bahasa Jawa. Akan tetapi, peran media ini mulai memudar karena kurangnya durasi tayang. Media cetak Jogja Panjebar Semangat, Jayabaya dll. kurang dalam keseriusan pengelolaan (Aribowo 2015). Di samping itu, cara tersebut sebenarnya sudah mulai ditinggakan oleh masyarakat. Masyarakat cenderung beralih ke media online dalam mencari berita dan hiburan.

Kedua, pemertahanan bahasa Jawa melalui regulasi dalam pendidikan. pemerintah melalui Permendikbud No 21 tahun 2016 mengimplementasikan pembelajaran bahasa Jawa dalam dunia pendidikan. Pada dunia pendidikan bahasa Jawa menjadi mata pelajaran muatan lokal yang harus diajarkan pada kurikulum di tingkat pendidikan dasar dan menengah. Cara ini, sebenarnya sangat ampuh untuk mempertahankan bahasa Jawa, karena siswa wajib mempelajarinya di bangku sekolah. Namun, pengajaran dalam sekolah perlu didukung cara lain yang mampu membuat generasi muda tetap memakai bahasa Jawa walaupun di luar kelas..

Ketiga, pemertahanan bahasa dilakukan dengan cara menyelenggarakan kegiatan bahasa Jawa, ilmiah maupun nonilmiah. Kegiatan tersebut seperti lomba dan festival kecakapan berbahasa (drama, macapat, mendongeng); serta diselenggarakannya sarasehan, seminar, dan kongres berbahasa Jawa. Akan tetapi usaha tersebut kurang dalam keseriusan sehingga dirasa kurang efektif (Aribowo 2015). 
Selain upaya yang kurang efektif, pemertahanan bahasa pada saat ini menghadapi tantangan yang semakin berat. Pandemi Covid-19 yang terjadi tidak hanya di Indonesia membuat segala upaya tersebut harus dievaluasi. Penyelenggaraan lomba, festival seminar, kongkres, pendidikan konvensiaonal dalam kelas, berkomunikasi di lingkungan sosial kini terbatasi dan tidak dapat dilakukan seperti biasanya. Masayarakat diminta untuk menjaga jarak, tidak boleh berkerumun demi memutus mata rantai penyebaran virus. Hal tersebut menuntut strategi baru dalam upaya pemertahanan bahasa Jawa.

Berdasarkan apa yang telah dijabarkan sebelumnya, perlu adanya upaya khusus dalam pemertahanan bahasa Jawa yang sesuai dengan zamannya, dan sesuai keadaan saat ini. Pemanfatan teknologi menjadi satu-satunya cara untuk berkemunikasi di era pandemi ini. Dengan kata lain pemanfaatan teknologi dalam jaringan menjadi pilihan untuk dikembangkan.

Kajian ini akan mencoba menawarkan solusi pemertahanan bahasa Jawa yang menyasar generasi muda dan dalam masa pandemi Covid-19. Lomba konten youtube berbahasa Jawa menjadi tawaran. Tawaran tersebut dipilih karena alasan berikut, Pertama, kreator youtube saat ini menjadi tren di kalangan anak muda; Kedua, konten youtube berbahasa Jawa memiliki banyak pengikut dan dilihat oleh banyak orang serta jangkauan konten youtube mampu menyasar seluruh lapisan masyarakat dengan pemakai terbesar anak muda; Ketiga, konten youtube memenuhi asas kemudahan dalam mengoprasikan dan tidak membutuhkan biaya yang tinggi, karena hanya memanfaatkan jaringan dalam internet serta alat yang dibutuhkan cukup gawai yang dimiliki oleh kebanyakan lapisan masyarakat. Keempat, Youtube adalah media sosial yang paling banyak dipakai masyarakat pada masa pandemi ini (databoks, 2020).

\section{METODE}

Pendekatan dalam kajian ini adalah pendekatan kualitatif. Pendekatan kualitatif bermaksud untuk memahami fenomena tentang apa yang dialami oleh subjek penelitian misalnya motivasi, persepsi, prilaku, dan tindakan. Secara holistik dengan cara deskripsi dalam bentuk kata-kata dan bahasa, pada suatu konteks khusus yang alamiah dan dengan memanfaatkan berbagai metode ilmiah (Moleong, 2010). Data dan informasi dalam kajian ini digali melalui berbagai studi literatur seperti Jurnal, artikel, buku, dan tulisan-tulisan yang telah terpublikasi maupun belum. Selain itu, penggalian informasi dilakukan dengan cara analisis video berupa tayangan konten youtube berbahasa Jawa yang viral . Teknik pengumpulan data sendiri melalui studi pustaka, dan dokumentasi.

Kajian ini bersifat deskriptif dan eksplanatif. Metode deskriptif dipilih untuk memaparkan berbagai data dan informasi yang telah diperoleh mengenai topik penelitian. Metode eksplanatif dipergunakan untuk mengungkap dan menjelaskan bagaimana sebuah fenomena sosial terjadi. Selanjutnya, hasil dari proses penelitian tersebut akan diambil sebuah kesimpulan berupa implikasi penelitian (Neuman, 1997).

Teknik pengolahan data dengan cara terlebih dahulu menelaah seluruh data yang tersedia dari berbagai sumber, dokumen pribadi, dokumen resmi, video konten youtube, jurnal, hasil penelitian, buku dan sebagainya. Setelah itu dilakukan reduksi data, yaitu merangkum memilih hal-hal yang pokok, memfokuskan hal-hal yang penting, dicari tema dan polanya. Kemudian dilakukan penyajian data dalam bentuk uraian singkat. Aktivitas dalam pengolahan data kualitatif dilakukan secara interaktif dan berlangsung secara terus menerus sampai tuntas. Aktivitas tersebut adalah reduksi data, penyajian data dan penarikan kesimpulan (Miles dan Huberman dalam Sugiyono, 2010). 


\section{HASIL DAN PEMBAHASAN}

Upaya dan strategi pemertahanan bahasa Jawa telah banyak dipaparkan dalam penelitian-penelitian terdahulu. Endang Nur Hayati dkk. dalam jurnal yang mereka tulis dengan judul "Strategi Pemertahanan Bahasa Jawa di Provinsi Daerah Istimewa Yogyakarta" (2013) meneliti faktor penyebab pergeseran pemakaia bahasa Jawa, upaya dan strategi pemerthanan Bahasa Jawa. Hayati dkk. memaparkan bahwa faktor penyebab pergeseran bahasa yaitu: 1) persepsi negatif terhadap bahasa Jawa khususnya golongan muda; 2) kehidupan sosial masyarakat yang semakin komplek; 3) Jumlah penutur bahasa jawa yang semakin menurun; 4) bahasa Jawa tidak lagi dipakai sebagai bahasa pertama dan komunikasi dalam keluarga. Dari penyebab tersebut Hayati dkk. merumuskan upaya pemertahanan bahasa yakni: 1) penguatan filosofi budaya dan bahasa Jawa; 2) perlunya diselenggarakan lomba dan festival bahasa Jawa; 3) pengembangan seni pertunjukan Jawa; 4) penyebaran nilai budi pekerti bahasa Jawa melalui ungkapan; 5) menggunakan bahasa Jawa di Instansi. Startegi yang ditawarkan Nurhayati dkk adalah, 1) memakai bahasa Jawa sebagai alat komunikasi sehari-hari; 2) penyatuan bahasa dan budaya; 3) menetapkan kebijakan melalui Pemda; 4) memasukkan pembelajaran bahasa Jawa dalam kurikulum pendidikan; 5) penggunaan bahasa Jawa dalam dunia jurnalistik dan; kegiatan LSM.

Geovani Julia Adhinata dan Saras Fairus Hemas dalam makalah yang berjudul "Variasi Bentuk Penamaan Badan Usaha Berbahasa Jawa: Startegi Pemertahanan Bahasa Jawa di Kota Semarang" (2017) penelitian yang berfokus pada penamaan badan usaha ini secara spesifik menyampaikan bahwa penggunaan bahasa Jawa pada badan usaha dapat dijadikan strategi pemertahanan bahasa Jawa.

Erik Kunto Aribowo dalam makalah yang berjudul "Pemanfaatan Smart Phone semaksimal Mungkin: Digitalisasi Produk Kebahasaan ke dalam Aplikasi Sebagai Solusi Mitigasi Pergeseran Bahasa Jawa" (2015) Makalah ini memberikan solusi alternatif dalam penggunaan teknologi, khususnya smartphone, dalam rangka mengatasi pergeseran bahasa dan menghadapi kepunahan bahasa. Solusi alternatif dicoba ditawarkan oleh Aribowo: 1) Melakukan digitalisasi buku kebahasaan, karya sastra baru maupun klasik dan kamus Bahasa Jawa dalam aplikasi. Sebagai daya pikat untuk generasi muda, (2) Menciptakan aplikasi komik digital berbahasa Jawa, berisi tentang cerita rakyat. Solusi tersebut bertujuan untuk mengurangi gaya hidup konsumtif terhadap produk asing. Selain itu, juga dilakukan agar cerita-cerita ataupun dongeng yang ada selama ini dapat dipublikasikan ke masyarakat luas dengan masif. Selain komik, e-book atau buku elektronik juga merupakan industri kreatif yang berpotensi tumbuh. (3) memberikan sentuhan multimedia (suara, gambar dan video) pada buku digital dengan harapan mampu memperkaya kosakata generasi muda sebagai sasaran. (4) Mengembangkan game-game edukatif bahasa Jawa. strategi tersebut menurut Aribowo perlu dilakukan karena fenomena penggunaan smartphone yang tinggi bagi generasi muda.

Miza Rahmatika Aini dalam makalah yang berjudul "Kesenian Jaranan Sebagai Bentuk Pemertahanan Bahasa Jawa" (2013) makalah ini memaparkan bahasa Jawa pada era globalisasi, banyak mengalami perubahan fungsi. Perubahaan itu dapat dilihat dari pergeseran bahasa Jawa dalam komunikasi sehari-hari yang jarang dipakai oleh penuturnya, hal tersebut lambat laun akan menggeser peran bahasa Jawa sebagai bahasa ibu. Secara spesifik Aini menyampaikan pergeseran tersebut terjadi pada pulau Jawa tempat dimana bahasa Jawa tumbuh dan berkembang. Di samping itu pergeseran bahasa Jawa juga dipengaruhi oleh banyaknya pendatang dan budaya luar yang masuk. Budaya luar seolah menawarkan prestisius sehingga lambat laut penggunaan bahasa Jawa dalam kebudayaan mulai tergeser. Berdasarkan hal tersebut Aini memanfaatkan kesenian Jaranan yang popular di Jawa Tengah sebagai alternatif upaya 
pemertahanan bahasa Jawa. di samping itu Jaranan mengandung banyak nilai filosofis masyarakat Jawa. Dalam makalahnya Aini menyajikan berbagai istilah, lagu, peralatan dan cerita Jaranan sebagai wujud pemertahanan bahasa Jawa.

Hari Bakti Mardikantoro, dalam makalahnya yang berjudul "pemertahanan Bahasa Jawa dalam Pertunjukkan Kesenian Tradisional di Jawa Tengah" (2016) tujuaan kajian ini adalah mencari bentuk pemertahanan bahasa Jawa dan mendeskripsikan faktor sosial budaya yang mempengaruhi bahasa Jawa dalam pertunjukan kesenian tradisional di Jawa Tengah. Hasil penelitian menunjukkan bahwa bentuk pemertahanan bahasa Jawa dalam pertunjukkan kesenian tradisional di Jawa Tengah meliputi bentuk prakata, tembang, doa, dan pantun. Faktor penyebab pemertahanan bahasa Jawa dalam pertunjukkan kesenian tradisonal di Jawa Tengah yakni upaya menjunjung tinggi budaya Jawa, daerah tempat tinggal/pertunjukan, keselarasan dengan gerak/tari dan musik/gamelan.

Meskipun terdapat kesamaan objek kajian ini dengan penelitian-penelitian terdahulu, penelitian ini memiliki perbedaan. Perbedaan dengan penelitian terdahulu sebagai berikut: Pertama, kajian ini dan penelitian-penelitian terdahulu sama-sama mengkaji objek pemertahanan bahasa Jawa, tetapi fokus kajian adalah upaya pemertahanan bahasa Jawa melalui lomba konten youtube di masa Pandemi Covid-19. Hal ini berbeda dengan penelitian-penelitian terdahulu yang berfokus pada strategi pemertahanan bahasa dengan cara konvensional yakni pertunjukkan dan kegiatan tradisional yang saat ini kegiatan tersebut dibatasi oleh pemerintah karena pandemi. Kajian Aribowo walaupun tidak menyasar aspek tradisonal akan tetapi fokusnya pada pemanfaatan smartphone, upaya yang ditawarkan masih sangat umum maka perlu cara yang lebih spesifik khususnya pada masa pandemi Covid-19. Kedua, fakta dilapangan menunjukkan bahwa kecenderungan bahasa Jawa ditinggalkan oleh penutur golongan muda. Upaya spesifik menyasar golongan muda belum pernah dilakukan khususnya pada masa pandemi ini. Kajian ini memaparkan dialektika antara situasi saat ini, strategi/ upaya pemertahanan bahasa Jawa, dan tren kecenderungan berbahasa anak muda pada saat ini.

\section{Pandemi Covid-19}

Coronaviruses (CoV) merupakan keluarga virus yang menyebabkan penyakit flu biasa/ringan hingga penyakit seperti Sindrom Pernafasan Timur Tengah (MERS-CoV) dan Sindrom Pernafasan Akut Parah (SARS-CoV). Penyakit Coronavirus 2019 (COVID19) merupakan virus corona jenis baru yang ditemukan pada tahun 2019 dan belum pernah teridentifikasi pada manusia sebelumnya. Virus corona adalah zoonosis, artinya ditularkan antara hewan dan manusia. Investigasi terperinci menemukan bahwa SARSCoV ditularkan dari kucing luwak ke manusia dan MERS-CoV dari unta dromedaris ke manusia. Beberapa coronavirus yang dikenal beredar pada hewan yang belum menginfeksi manusia.

Tanda-tanda umum infeksi termasuk gejala pernapasan, demam, batuk, sesak napas dan kesulitan bernafas. Pada kasus yang lebih parah, infeksi dapat menyebabkan pneumonia, sindrom pernapasan akut, gagal ginjal, dan bahkan kematian.

World Health Organization (WHO) pada 11 Maret 2020 sudah mengumumkan status pandemic global penyakit virus corona 2019 atau seing disebut corona virus disease 2019 (COVID-19). Dalam istilah kesehatan, pandemi diartikan sebagai terjadinya wabah penyakit yang menyerang banyak korban, bersamaan di berbagai penjuru negara. WHO menetapkan Covid-19 sebagai pandemi disebabkan karena seluruh warga dunia berpotensi terjangkit infeksi. Dan ditetapkan sebagai masa darurat Internasional. 
Pemerintah Indonesia melalui Gugus Depan percepatan penanganan pandemi covid-19 pembatasan akses. Pembatasan akses Dalam respon penanganan pandemi COVID-19, pembatasan akses sangat dimungkinkan, untuk mengantisipasi eskalasi risiko yang terjadi, khususnya dalam pontensi meluasnya pandemi yang terjadi. Pertama, menerapkan Pembatasan Sosial Berskala Besar(PSBB). PP No.21 Tahun 2020 tentang Pembatasan Sosial Berskala Besar dalam Rangka Percepatan Penanganan COVID-19, telah mengatur dan menetapkan definisi dari Pembatasan Sosial Berskala Besar atau PSBB adalah pembatasan kegiatan tertentu penduduk dalam suatu wilayah yang diduga terinfeksi COVID-19 sedemikian rupa untuk mencegah kemungkinan penyebarannya. Kedua, Larangan penyelenggaraan kegiatan Masal (non PSBB) Dalam situasi yang diindikasikan bahwa adanya daerah yang sudah mendapati kasus positif COVID-19 (non PSBB), sebagai upaya untuk mengantisipasi terjadinya penularan dalam skala masif, maka pemerintah daerah dapat membuat kebijakan yang sesuaikan untuk pembatasan kegiatan, pengaturan jam efektif hingga larangan kegiatan.

\section{Aktualisasi Bahasa Jawa Youtuber Upaya Pemertahanan Bahasa}

Youtube merupakan media sosial berupa situs video yang memiliki fungsi sebagai media berbagi video dalam jaringan secara online. Youtube menawarkan citra sebuah situs yang memiliki fungsi sama dengan stelevisi yang berisi beragam video dan acara (Enterprise, 2008:53). Situs tersebut didirikan oleh Chad Hurley, Jawed Karim dan Steve Chen mantan karyawan PayPal perusahaan pembayaran online pada Februari 2005, ketika mereka merasa prustasi saat mengirim e-mail yang berisi klip video (Herwibowo: 2008:19).

Youtube menawarkan kepada pengguna menonton video, berbagi klip video dan memproduksi video sendiri secara gratis. Kebayakan video yang ada di Youtube adalah Film, klip musik (video klip), TV, serta video buatan para penggunanya sendiri (Waters, 2010:121).

Di Indonesia saat ini youtube telah menjadi tren. Dari siswa hingga mahasiswa, dari pengusaha kecil sampai besar, dari orang biasa sampai artis, dari rakyat sampai pejabat, banyak yang memiliki konten youtube. Youtube kini sangat dominan menguasai media sosial Indonesia. Youtube selain diulas dalam beberapa media, Youtube pun banyak dibahas di jalur online. Kisah kesuksesan para pendiri nya banyak dijadikan contoh oleh para konten kreator (youtuber) yang lain (Herwibowo, 2008:11).

Salah satu konten video yang sedang viral pada masa pandemi Covid-19 saat ini adalah konten youtube yang berjudul "DAGELAN JOWO Eps. 06-Teh Kesukaan Simbok Minto"

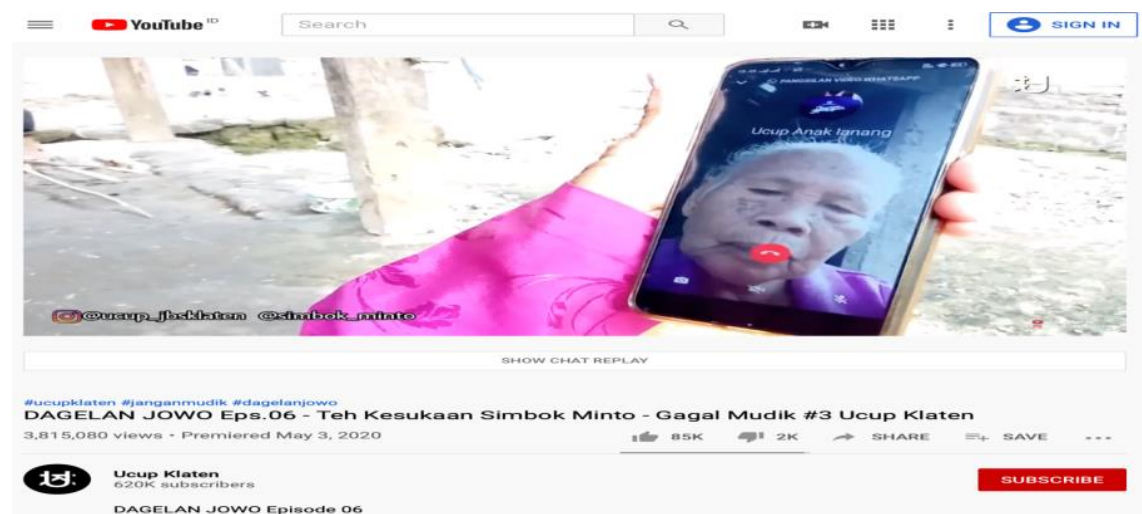

Gambar 1: Tampilan konten video youtube channel Ucup kelaten 19 Mei 2020 
Konten video youtube dengan subjek "Dagelan Jowo Eps.06-Teh Kesukaan Simbok Monto-Gagal Mudik" diunggah channel Ucup Klaten. Konten tersebut mengisahkan seorang nenek (ibu) yang kangen anaknya. Masa pandemi Covid-19 di bulan puasa membuat kampungnya sepi karena banyak orang tidak dapat mudik, tidak seperti tahun-tahun sebelumnya yang selalu ramai. Sembari menunggu berbuka puasa, sinenek menghubungi putranya melalui video call, mereka membahas tentang teh kesukaan si mbok ya itu Teh Ha eR (Tunjangan Hari Raya/THR). Sang anak yang hidup di perantauan tidak bisa mudik karena pandemi Covid-19, merasa bingung karena ibunya minta ditransfer THR. Sang anak mempunyai ide untuk mengirim barang seadanya agar ibunya bahagia. Konten dengan berbahasa Jawa yang diunggah tanggal 3 Mei 2020 ini telah dilihat oleh 3, 815,080 disukai oleh 85 ribu orang. Keviralan video tersebut juga dimuat diberbagai media online seperti regional.kompas.com, ww.solopos.com, jateng.tribunnews.com. jateng,suara.com, news.detik.com, radarsolo.jawapos.com, www.kompas.tv. Jateng,inews.id, otomania.gridoto.com, ww.hitekno.com.

Selain channe/ Ucup Klaten, channel berbahasa Jawa yang lebih dulu kontennya viral dan memiliki banyak pengikut, yakni Nyekiklik, Ruwet TV dan Bayu Skak. Channel youtube dengan konten bahasa Jawa selanjutnya adalah Nyekikilik.

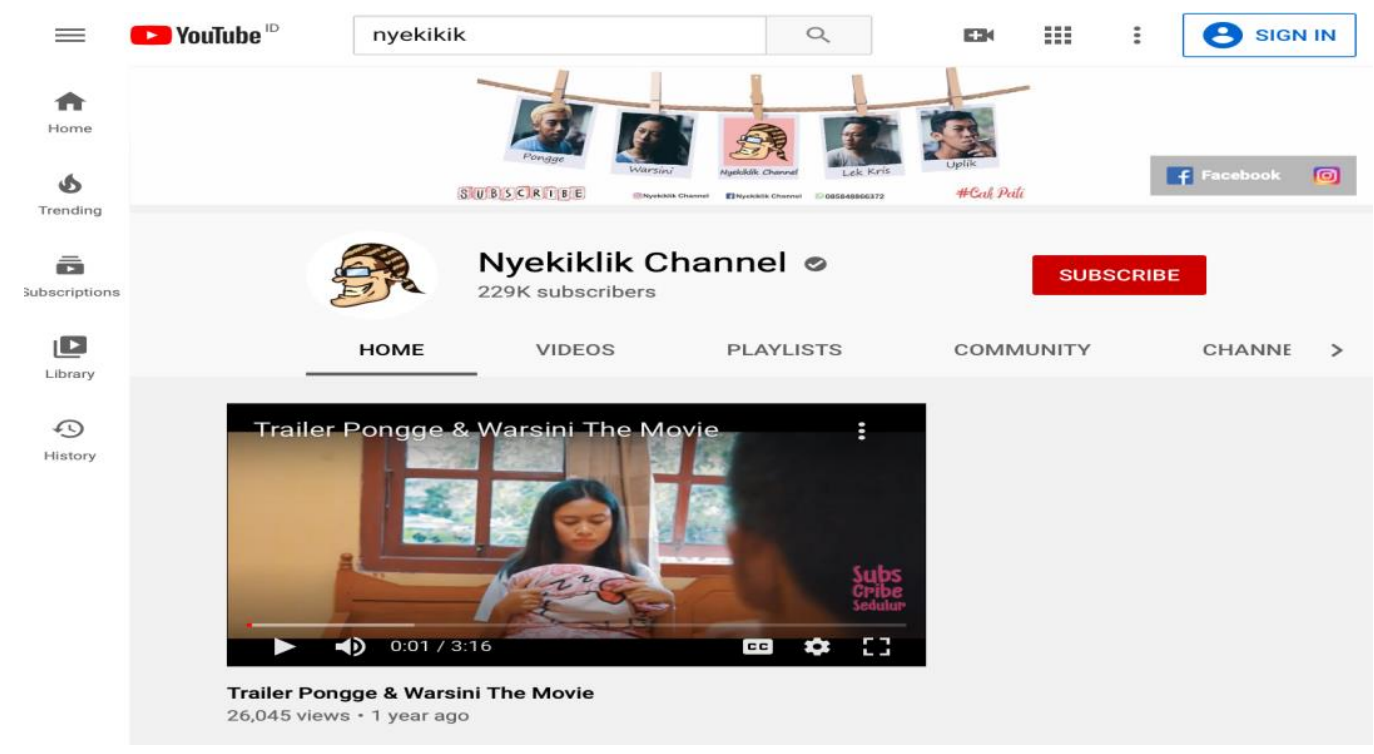

Gambar 2: tampilan beranda channel Nyekiklik 19 Mei 2020

Channel nyekikilik merukan kreasi dari pemuda Pati Jawa Tengan. Kontenkonten yang mereka produksi berbahasa Jawa dan bergenre komedi. Channel tersebut memiliki pengikut 229.000. Conten yang mereka unggah paling banyak dilihat oleh 641 ribu kali dengan subjek konten Cawet Goyang (Cover Parodi Jaran Goyang) diunggah pada 16 Desember 2017. Konten paling sedikit dilihat 14.000 orang dengan subjek konten "Salah Masker-Film Komedi Jowo Lucu" di unggah pada tanggal 09 Mey 2020.

Selanjutnya channel berbahasa Jawa dengan pengikut banyak adalah Ruwet TV. 


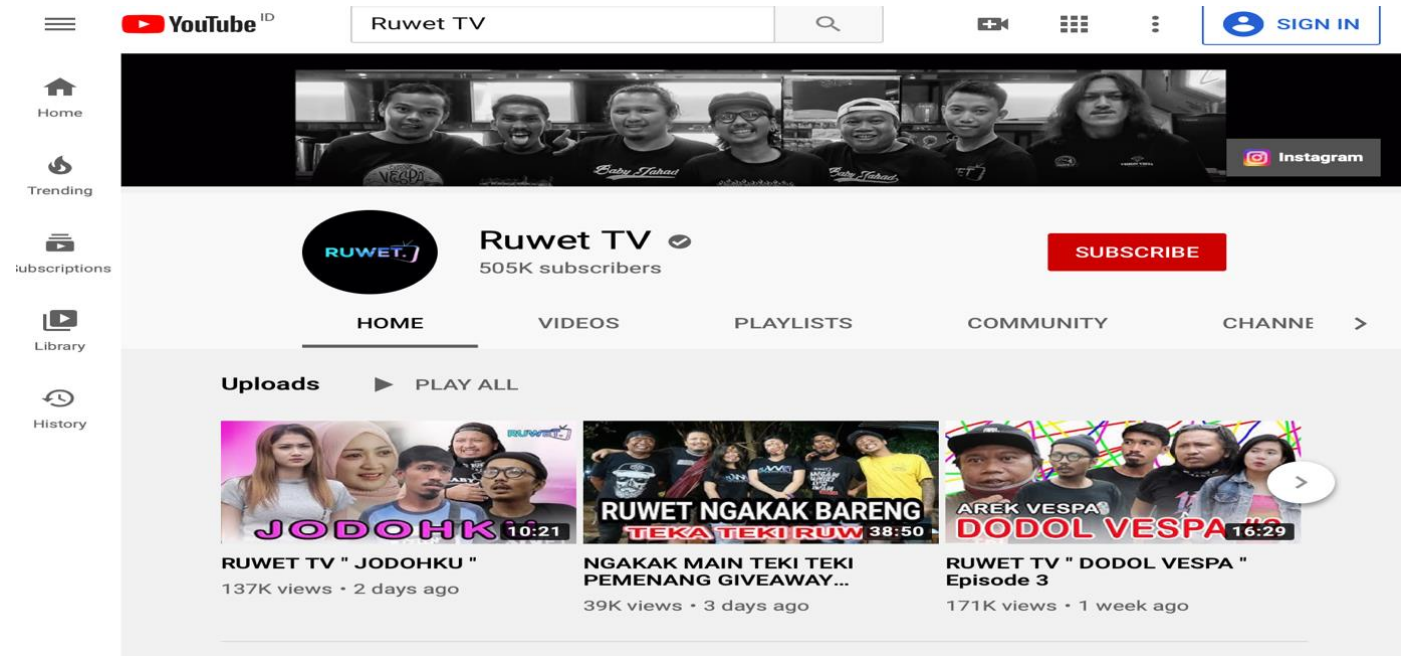

Gambar 3: Tampilan beranda channel Ruwet TV 19 Mei 2020

Ruwet TV merupakan channel youtube dengan konten berbahasa Jawa yang memiliki banyak pengikut. Pengikutnya menembus angka 505.000 dengan judul konten paling banyak dilihat "Mafia Jambret Ruwet TV Feat Dani Creator" 2 Milyar kali dilihat. Channel youtube selanjutnya yang memiliki banyak pengikut adalah Bayu Skak.

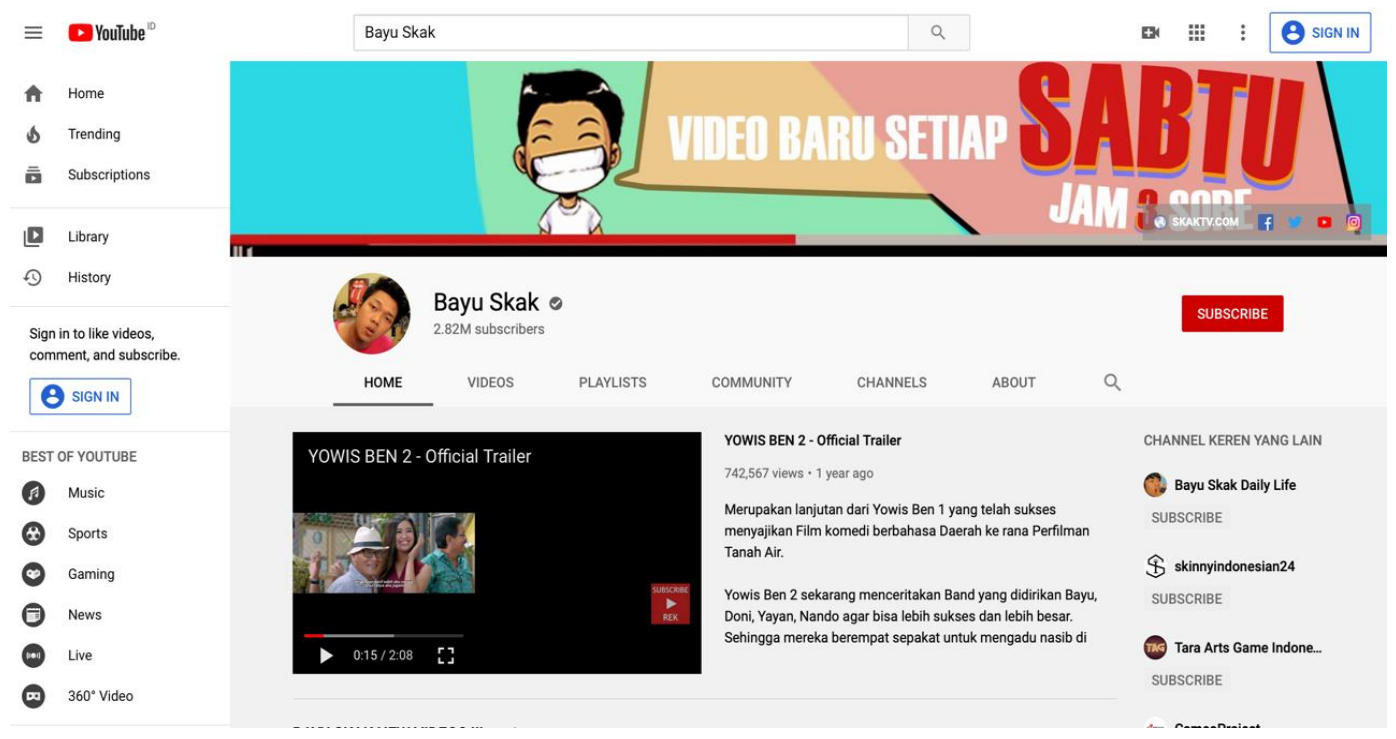

Gambar 4: Tampilan beranda channel Bayu Skak 19 Mei 2020

Channel Bayu Skak merupakan nama channel youtube dan nama panggilan Bayu Eko Moekito. Youtuber yang lahir di Malang ini pada tahun 2017 mendapatkan Golden Play Button dari Youtube. la konsisten menggunakan bahasa Jawa dalam setiap kontennya. Saat ini pengikut Bayu Skak mencapai 2,82 M. pencapaian yang luar biasa konten youtube yang berbahasa Jawa.

Pada tahun 2010 Bayu menginisiasi film 'Yowis Ben'. Film berbahasa Jawa pertama yang tayang di seluruh bioskop Indonesia. Meraup jumlah satu juta penonton pada penayangannya. Bahkan, mendapatkan dukungan dari Presiden RI Joko Widodo, hingga Menteri Pendidikan dan Kebudayaan RI, Muhadjir Effendy.

Channel Ucup Klaten, Nyekiklik, ruwet TV dan Bayu Skak, mampu menjadi perantara menuju ketenaran bagi kreatornya yang memanfaatkan media online. Cara seperti ini dilakukan oleh para Youtuber dengan berlomba-lomba membuat konten 
kreatif. para yotuber tersebut konsisten memakai bahasa Jawa dalam setiap konten yang mereka buat ditambah ekspresi unik menjadikan hal tersebut sebuah fenomena yang menarik respon penonton. Dari apa yang mereka lakukan mereka mendapatkan popularitas. Popullaritas sebagai youtuber dapat terjadi apabila seseorang atau sekelompok orang menjadi viral di media sosial, maka akan dikenal oleh publik. Menurut Rahmawan dan Narotama (2017). Secara ekonomi, seorang youtuber juga dapat menghasilkan penghasilan yang tidak sedikit dari konten yang mereka produksi.

Seperti apa yang telah dijabarkan di atas, banyak youtuber yang membuat konten youtube dengan menggunakan bahasa Jawa meraih kesuksesan. Pemanfaatan youtube sebagai sarana pemertahanan bahasa Jawa pada saat ini sangat menjanjikan. Beberapa saluran youtube yang dikaji di atas menunjukkan, penggunaan bahasa Jawa dalam konten yang mereka buat tidaklah menutup akses kesuksesan bagi mereka untuk menjadi terkenal. Bayu Skak mampu meraih pengikut 2,82 M pencapaian yang luar biasa. Penutur bahasa Jawa oleh Crystal (dalam Lauder, 2004) disebutkan di Indonesia penuturnya 75,2 juta, akan tetapi Bayu mampu meraih pengikut 2,82 $\mathrm{M}$ hal ini menunjukkan bahwa pecinta Bayu Skak bukan hanya masyarakat Jawa melainkan masyarakat diluar penutur bahasa Jawa juga. Dengan kata laian Bayu telah mengenalkan kosakata bahasa Jawa pada 2,6 M masyarakat di luar penutur asli Bahasa Jawa. hal tersebut menjadi strategi yang ampuh dalam upaya pemertahanan bahasa Jawa.

Melihat fenomena konten berbahasa Jawa, pemerintah memalui badan pemertahanan bahasa dapat menjadikan fenomena ini sebagai upaya pemertahanan bahasa daerah. Upaya tersebut dapat dilakukan melalui lomba konten youtube berbahasa Jawa. Lomba konten kreatif youtube berbahasa Jawa perlu diambil sebagai langkah strategis pemertahanan bahasa, secara terjadwal dan masuk dalam rancangan kerja jangka pendek maupun jangka panjang badan pemertahanan bahasa daerah. Hal tersebut juga didasari atas apa yang telah dijabarkan sebelumnya dalam pendahuluan, bahwa perlu adanya upaya khusus dalam pemertahanan bahasa Jawa yang sesuai dengan zamannya, dan sesuai keadaan saat ini. lomba konten youtube berbahasa Jawa memenuhi asas tersebut. Pembuatan konten youtube tidak perlu mengumpulkan masa yang banyak sehingga tidak melanggar apa yang telah ditetapkan oleh pemerintah dalam penanggulangan virus Covid-19. Disamping itu, pembuatan konten youtube memenuhi asas kemudahan dalam mengoprasikan dan tidak membutuhkan biaya yang tinggi, karena hanya memanfaatkan jaringan dalam internet serta alat yang dibutuhkan minimal gawai. yang terpenting Youtube adalah media sosial yang paling banyak dipakai masyarakat pada masa pandemi ini (databoks, 2020). Pada era pandemi seperti saat ini aktivitas masyarakat tidak jauh dari teknologi dan internet. Strategi lomba konten youtube menjadi hal yang tepat sebagai upaya pemertahanan bahasa Jawa pada masa pandemic Covid-19.

\section{SIMPULAN}

Upaya pemertahanan bahasa yang telah dilakukan pemerintah perlu menyeseuaikan kedaan saat ini. pada masa pandemi Covid-19 segala aktivitas masyarakat telah dibatasi oleh pemerintah. Proses sosial tidak dapat dilakukan seperti sebelum pandemi. Kegiatan pemertahanan bahasa melalui cara pengumpulan masa seperti lomba, seminar tidak diperkenankan dilaksanakan. Penggunaan bahasa Jawa di sekolah hanya sebatas pada pembelajaran bahasa Jawa. Upaya pemertahanan bahasa Jawa melalui berita dan hiburan di media massa televisi memiliki kendala jam tayang yang sedikit, cara ini juga sudah mulai ditinggalkan oleh masyarakat. Pemanfaatan media cetak berbahasa Jawa kurang mendapat perhatian serius, hal tersebut mendasari perlunya alternatif lain dalam upaya pemertahanan bahasa Jawa. 
Youtuber melalui konten berbahasa Jawa mampu memperoleh pengikut yang banyak dan dapat mengenalkan bahasa Jawa tidak hanya pada penutur aslinya dan, berterima di generasi muda yang menjadi pemakai terbesar aplikasi youtube. Konten yotube berbahasa Jawa dapat dijadikan upaya alternatif dalam pemertahanan bahasa Jawa melalui lomba konten berbahasa Jawa.

Lomba konten berbahasa Jawa pada massa pandemi tidak menyalahi aturan pemerintah dalam penanggulangan penyebaran virus Covid-19, karena kegiatan tidak diselenggarakan dengan mengumpulkan massa seperti kegiatan yang selama ini telah diselenggarakan pemerintah, kegiatan dilaksanakan dalam jaringan. Youtube memiliki jangkauannya yang luas mudah dan tidak membutuhkan biaya mahal dalam pengerjaannya sehingga dapat dijadikan alat yang murah dalam pemertahanan bahasa.

\section{DAFTAR RUJUKAN}

Adinatha, Giovani Julia, and Saras fairus hemas. "Variasi Bentuk Penamaan Badan usaha Berbahasa jawa: strategi Pemertahanan Bahasa Jawa di Kota Semarang." International Seminar on Language Maintenance and Shift (LAMAS)7. Semarang: Master Program in Linguistics, Diponegoro University in Colaboration With Balai Bahasa Jawa Tengah, 2017. 227-233.

Aini, Miza Rahmatika. "Kesenian Jaranan sebagai Bentuk Pemertahanan Bahasa Jawa." International Seminar Language Maintenance and Shift III . Semarang: Master Program In Lingusitics Diponegoro University in Collaboration With Balai Bahasa Privinsi Jawa Tengah, 2013. 305-308.

Aribowo, Eric Kunto. "PEMANFAATAN SMARTPHONE SEMAKSIMAL MUNGKIN: DIGITALISASI PRODUK KEBAHASAAN KE DALAM APLIKASI SEBAGAI SOLUSI MITIGASI PERGESERAN BAHASA JAWA." Magistra, 2015: 21-28.

Fasold, R.W. The Sociolinguistcs of Society. Oxford: Basil Blackwell, 1984.

Ferguson, Gibson. Language Planning and Education. Edinburg: Edinburg University Press Ltd, 2006.

Gumperz, J.J. Language in Social Groups. Stanford: Stanford University Press, 1971.

Hanna. "Bahasa Daerah Pada Era Globalisasi Peluang Dan Tantangan ." International Seminar "Language Maintenance and Shift II. Semarang : Master Program in Linguistics, Diponegoro University in Collaboration With Balai bahasa Jawa Tengah, 2012. 1-8.

Mardikantoro, Hari Bakti. "Pemertahanan Bahasa Jawa dalam Pertunjukkan Kesenian Tradisional di Jawa tengah." LITERA, 2016: 269-280.

Mbete, Aron Meko. "Strategi Pemertahanan Bahasa-Bahasa Nusantara." Seminar Internasional Language Maintenance and Shift. Semarang: Program Pascasarjana Linguistik Universitas Diponegoro, 2010. 1-11.

N, Eduardus Swandy. "Bahasa Gaul Remaja dalam Media Sosial Fecbook." Jurnal Bastra, 2017: 1-19.

Nurhayati, Endang, and Hesti Mulyani dan Suwardi Mulyana.

"StrategiPemertahananBahasaJawadiProvinsiDaerahlstimewaYogyakarta." Lentera, Jurnal Penelitian Bahasa, Sastra, dan Pengajarannya, 2013: 159-166. 


\section{Internet}

10 Media Sosial yang Paling Sering Digunakan di Indonesia

https://databoks.katadata.co.id/datapublish/2020/02/26/10-media-sosial-yang-palingsering-digunakan-di-indonesia 